\title{
Survival and Growth of Listeria monocytogenes on Fresh-Cut Apple Slices and Its Interaction with Glomerella cingulata and Penicillium expansum
}

William S. Conway, Britta Leverentz, and Robert A. Saftner, Horticultural Crops Quality Laboratory, Beltsville Agricultural Research Center, United States Department of Agriculture-Agricultural Research Service (USDAARS), Beltsville, MD 20705; Wojciech J. Janisiewicz, Appalachian Fruit Research Station, USDA-ARS, 45 Wiltshire Road, Kearneysville, WV 25430; Carl E. Sams, Department of Plant and Soil Sciences, The University of Tennessee, Knoxville 37901; and Eric Leblanc, Biometrical Consulting Service, USDA-ARS-BA-OD, Beltsville, MD 20705

\begin{abstract}
Conway, W. S., Leverentz, B., Saftner, R. A., Janisiewicz, W. J., Sams, C. E., and Leblanc, E. 2000. Survival and growth of Listeria monocytogenes on fresh-cut apple slices and its interaction with Glomerella cingulata and Penicillium expansum. Plant Dis. 84:177-181.

The food-borne human pathogen Listeria monocytogenes survived and its populations increased on cv. Delicious apple slices at 10 or $20^{\circ} \mathrm{C}$ in air or controlled atmosphere of $0.5 \% \mathrm{O}_{2}$ and $15 \%$ $\mathrm{CO}_{2}$, but did not grow at $5^{\circ} \mathrm{C}$. Controlled atmosphere had no significant effect on the survival or growth of L. monocytogenes. The pathogen populations declined over time when grown in various concentrations of apple juice and the decline was greater as the concentration of the juice decreased. Populations of $L$. monocytogenes inoculated into decayed apple tissue continually increased on fruit decayed by Glomerella cingulata but did not survive after 5 days on fruit decayed by Penicillium expansum. The $\mathrm{pH}$ of the decayed area declined from $\mathrm{pH} 4.7$ to 3.7 in the case of $P$. expansum, but in the case of $G$. cingulata the $\mathrm{pH}$ increased from $\mathrm{pH} 4.7$ to 7.0. This $\mathrm{pH}$ modification may be responsible for affecting the growth of the food-borne pathogen. Storage temperature, as well as the absence of postharvest pathogens such as G. cingulata, is important for maintaining the safety of fresh-cut apples.
\end{abstract}

Additional key words: bacterial human pathogen, CA, fruit acidity, fungal pathogen

The preparation and packaging of freshcut produce is a rapidly developing industry which offers the consumer both convenient and nutritious food. Along with the development of this industry, new problems may arise in the area of food safety. There is very little knowledge concerning the microbial contamination of fresh-cut fruits and vegetables. Outbreaks of illnesses from consuming intact fruits and vegetables seem to occur less frequently than from other foods such as meat and dairy products $(1,2,4,6)$. This may be the result of the physical and chemical barrier provided by the peel or rind, which prevents the establishment of microbes on the surface of the produce (6). This barrier is

Corresponding author: W. S. Conway

E-mail address: wconway@asrr.arsusda.gov

Use of a company or product name by the U.S. Department of Agriculture does not imply approval or recommendation of the product to the exclusion of others which may be suitable.

Accepted for publication 9 November 1999.

Publication no. D-1999-1215-02R

This article is in the public domain and not copyrightable. It may be freely reprinted with customary crediting of the source. The American Phytopathological Society, 2000. removed during the processing of fruit for the fresh-cut market and may result in the establishment of high populations of foodborne human pathogens, leading in turn to increased health hazards. Therefore, it is necessary to obtain information on the fate and control of food-borne pathogens on fresh-cut fruit.

Listeria monocytogenes (Murray et al.) Pirie is a facultative, Gram-positive bacterium that has been associated in recent years with a number of outbreaks of the food-borne illness listeriosis. This microorganism has the ability to withstand extremes in $\mathrm{pH}$ and low temperatures (13). Dairy products have received the most attention as a source of listeriosis, but this bacterium has also been found in beef, pork, poultry, and seafood (7). Its presence on fruits and vegetables has been less often reported but, recently, salad vegetables such as cabbage, celery, lettuce, cucumber, onion, leeks, watercress, and fennel were found to contain high populations of $L$. monocytogenes (15). In the United States, the bacterium has been found on individual fresh produce, such as cabbage, potatoes, cucumbers, and radishes, as well as other vegetables (9). However, during the past 10 years, there have been no confirmed outbreaks on produce attributed to $L$. monocytogenes (Center for Science in the

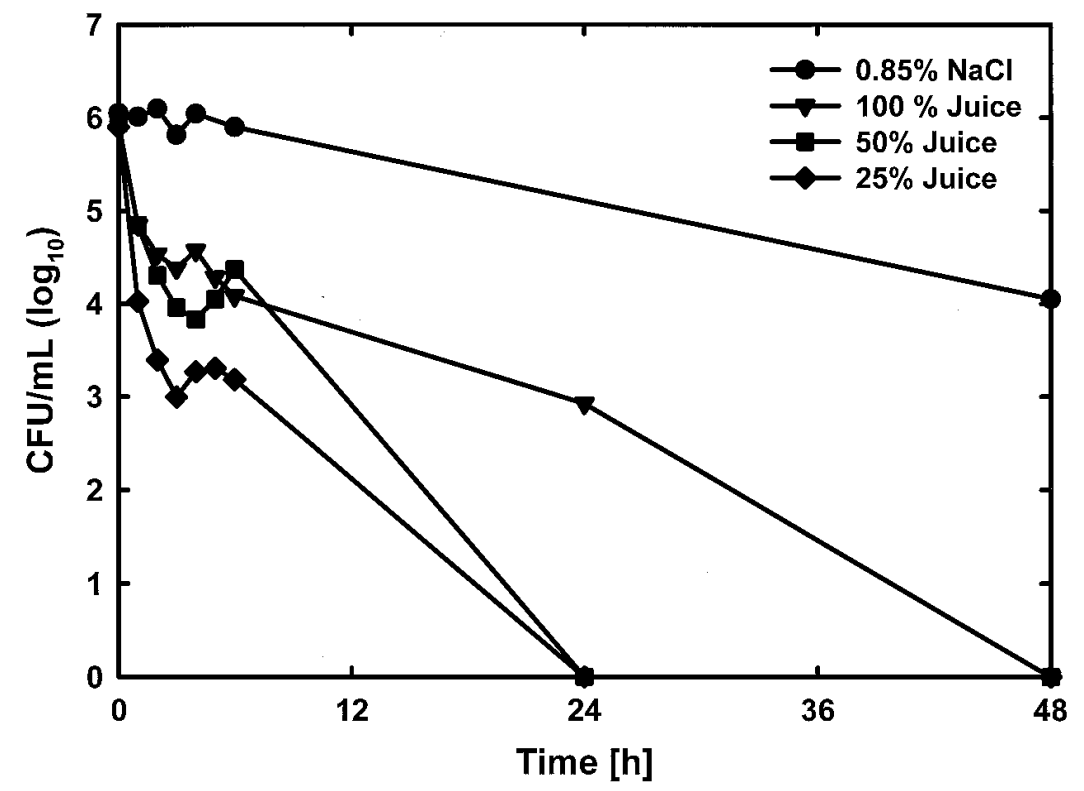

Fig. 1. Survival of Listeria monocytogenes in various concentrations of apple juice and in saline solution. Juice was inoculated with the bacterium and placed on a shaker, and populations were recovered at various periods of time. 
Public Interest, Lucy Alderton, personal communication). Little work has been done regarding the capacity of fruit to support the survival or growth of this pathogen. In addition to the effect of environmental factors on the growth of the bacterium on apple slices, there also may be a significant interaction between plant and human pathogens. For example, Wells et al. (18) recently found that populations of Salmonella spp. in wash water of vegetables and fruit that were affected with soft-rot were twice as high as those on healthy produce.

The objective of this research was to determine survival and growth of $L$. monocytogenes on fresh-cut apple slices and in apple juice, and the interaction of this bacterium with postharvest apple pathogens. We also investigated the growth of $L$. monocytogenes on apple slices as affected by storage temperature, controlled atmosphere, growth temperature, and concentration of the inoculum.
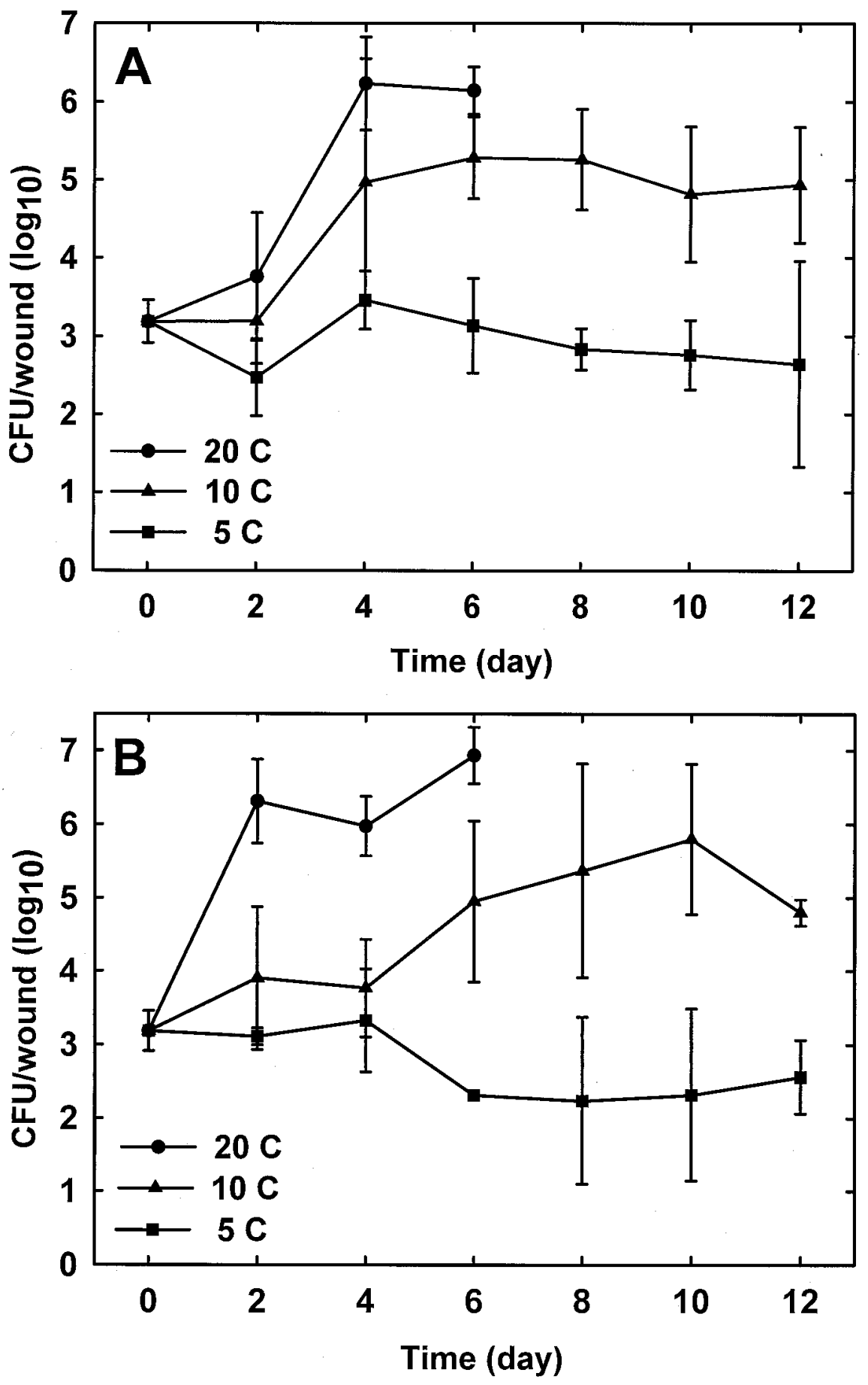

Fig. 2. Recovery of Listeria monocytogenes from cv. Delicious apple slices as affected by storage atmosphere. The slices were inoculated with the bacterium $\left(1 \times 10^{6} \mathrm{CFU} / \mathrm{ml}\right)$ and populations recovered after incubation in (A) air or (B) controlled atmosphere $\left(0.5 \% \mathrm{O}_{2}\right.$ and $\left.15 \% \mathrm{CO}_{2}\right)$ at the indicated temperatures for various periods of time. Vertical bars indicate standard errors of the means.

\section{MATERIALS AND METHODS}

Preparation of $L$. monocytogenes and fungal inoculum. The $L$. monocytogenes culture used in our experiments was strain LCDC 81-861 (obtained from Robert Brackett, Department of Food Science and Technology, University of Georgia, Agricultural Experiment Station, Griffin 30223). For inoculation of the apples or apple slices, L. monocytogenes cultures were grown overnight in tryptic soy broth (TSB; Difco Laboratories, Detroit, MI) at $30^{\circ} \mathrm{C}$ and $125 \mathrm{rpm}$. The cultures were harvested by centrifugation at $2,000 \times g$ for 10 min, resuspended in saline solution $(0.85 \%$ $\mathrm{wt} / \mathrm{vol} \mathrm{NaCl}$ ), and adjusted to $85 \%$ transmission at $420 \mathrm{~nm}$ (Shimadzu UV/vis-160 spectrophotometer, Shimadzu Scientific Instruments Inc, Columbia, MD). The inoculum was diluted to a concentration of about $1 \times 10^{5} \mathrm{CFU} / \mathrm{ml}$ before being added to the wound, unless otherwise noted. It was spiral plated and counted after one day to determine the exact cell concentration of the inoculum. For inoculation of the apple juice, the bacteria were resuspended in water rather than in saline solution.

Fungal cultures were grown on potato dextrose agar (PDA) for a minimum of 6 days at $20^{\circ} \mathrm{C}$ before inoculation. The very aggressive isolate Penicillium expansum Link was originally taken from a decayed apple in storage. The Glomerella cingulata (Stoneman) Spauld. \& H. Schrenk isolate was obtained from Ken Hickey at the Penn State Fruit Lab and Extension Center, Biglerville, Pennsylvania. Conidia were harvested and conidial suspensions were adjusted to $10^{6}$ conidia/ml using a haemocytometer. All experiments were repeated at least once.

Survival of $L$. monocytogenes in apple juice. Apple juice was made from cv. Delicious apples that were surface sterilized with $70 \%$ ethanol and ground in a household juicer. The juice was filter sterilized. Juice $(100 \mathrm{ml})$ at full strength and diluted to 50 and $25 \%$ with water was added to 250-ml Erlenmeyer flasks and the $\mathrm{pH}$ was determined before inoculation and over the period of the experiment (Mettler-Toledo combination $\mathrm{pH}$ electrode attached to a Biostat E Fermenter; B. Braun, Melsungen, Germany). The juice was then inoculated with $1 \mathrm{ml}$ of a $L$. monocytogenes suspension at a concentration of $1 \times 10^{6}$ $\mathrm{CFU} / \mathrm{ml}$. A similar flask containing $100 \mathrm{ml}$ of saline solution was inoculated as a control. The flasks were placed at $26^{\circ} \mathrm{C}$ on a shaker at $150 \mathrm{rpm}$. Samples were taken hourly for the first $6 \mathrm{~h}$ and then at 24 and 48 $\mathrm{h}$ after inoculation. Each sample was diluted 10 -fold to ensure countable concentrations and was then plated in duplicate onto tryptic soy agar (TSA) plates with a spiral plater (Autospiral DW; Don Whitley Scientific Limited, West Yorkshire, England). After 2 days of incubation at $30^{\circ} \mathrm{C}$, the plates were read with a Protos plate reader (Synoptics Ltd., Cambridge, England). 
Growth of L. monocytogenes on apple tissue. For all experiments, cv. Delicious apples were removed from storage in air $\left(0^{\circ} \mathrm{C}\right)$ after 4 to 8 months, allowed to warm overnight, and surface sterilized with $70 \%$ ethanol before being used in the experiments. A L. monocytogenes suspension (25 $\mu \mathrm{l})$ at a concentration of $1 \times 10^{6} \mathrm{CFU} / \mathrm{ml}$ was pipetted into a cavity $(8 \mathrm{~mm}$ in diameter and $4 \mathrm{~mm}$ deep) made in the apple tissue, unless otherwise noted.

To recover $L$. monocytogenes from either the whole fruit or slices, a cylinder of apple tissue $(1 \mathrm{~cm}$ in diameter and $1 \mathrm{~cm}$ deep) containing the entire wound was removed with a sterile cork borer, placed in a stomacher bag with $4.5 \mathrm{ml}$ of peptone water ( $\mathrm{pH}$ 7.4) (14), and then blended in a Stomacher blender (Stomacher 80; Seward Medical, London) for $2 \mathrm{~min}$ at normal speed. Buffered peptone water was used for a better resuscitation of injured cells and reduction of the lag phase to obtain higher recovery rates at shorter incubation times (14). The resulting slurry was filtered through glass wool and plated as described above.

Effect of inoculum concentration. Apple cores were removed and the fruit was cut into eight equal slices. A cavity was cut in the center of each slice. A L. monocytogenes suspension $(25 \mu \mathrm{l})$ at $1 \times 10^{6}, 1 \times$ $10^{7}$, or $1 \times 10^{8} \mathrm{CFU} / \mathrm{ml}$ was pipetted into the cavity. Three slices per treatment were placed in a 950-ml Mason jar and stored at 20,10 , or $5^{\circ} \mathrm{C}$ in air $\left(20.94 \% \mathrm{O}_{2}\right.$ and $0.35 \% \quad \mathrm{CO}_{2}$ ) or controlled atmosphere $\left(0.5 \% \mathrm{O}_{2}\right.$ and $\left.15 \% \mathrm{CO}_{2}\right)$. The balance was made up with $\mathrm{N}_{2}$. The slices were removed for sampling at 0,24 , and $72 \mathrm{~h}$ after inoculation. The samples were processed as previously described and colonies were counted.

Effect of atmosphere and temperature. Apples were sliced, inoculated with $L$ monocytogenes, and stored in air or controlled atmosphere as previously described. Three fruit slices each were placed in 950ml Mason jars at 20,10 , and $5^{\circ} \mathrm{C}$ with humidified air or appropriate gas passing through the jar at $15 \mathrm{ml} / \mathrm{min}$. Slices were sampled for bacterial growth every $48 \mathrm{~h}$. Slices incubated at 5 or $10^{\circ} \mathrm{C}$ were sampled for colony growth over a period of 13 days while those incubated at $20^{\circ} \mathrm{C}$ were sampled over a period of 6 days due to rapid deterioration of the slices.

To study the effect of temperature on the growth of L. monocytogenes, four apple slices were inoculated with $25 \mu \mathrm{l}$ of $1.2 \times$ $10^{3} \mathrm{CFU}$ of the bacterium, randomly placed in 950-ml Mason jars with humidified air and incubated at 20,10 , or $5^{\circ} \mathrm{C}$. Samples to quantify populations of $L$. monocytogenes were taken at $2 \mathrm{~h}$ (time zero) and 2, 5, and 7 days after inoculation.

Effect of culture growth conditions of L. monocytogenes. Apple slices were inoculated with a $L$. monocytogenes culture $\left(7.3 \times 10^{5} \mathrm{CFU} / \mathrm{ml}\right)$ grown either at 30 or $5^{\circ} \mathrm{C}$. The $30^{\circ} \mathrm{C}$ culture was grown overnight on a shaker after inoculation with cells from a $30^{\circ} \mathrm{C}$ pre-culture. The $5^{\circ} \mathrm{C}$ culture was inoculated with L. monocytogenes cells grown for 2 months at $5^{\circ} \mathrm{C}$ and placed on a shaker for 3 days at $10^{\circ} \mathrm{C}$, followed by 2 days at $5^{\circ} \mathrm{C}$. After inoculation, the samples were incubated at 20,10 , or $5^{\circ} \mathrm{C}$ and the bacteria were recovered at 0 , 2,5 , and 7 days after inoculation, as described above.

Interactions between $L$. monocytogenes and postharvest pathogens. Prior to inoculations, whole apples were wounded to a depth of $6 \mathrm{~mm}$ with the tip of a disinfected ten-penny-nail, approximately $4 \mathrm{~mm}$ in diameter at the base. Wounds on apples were inoculated with $25 \mu$ of a conidial suspension $\left(10^{6} / \mathrm{ml}\right)$ of $G$. cingulata or $P$. expansum. Tween $20(0.20 \%$ $\mathrm{wt} / \mathrm{vol}$ ) was added to the water control and the conidial suspensions to ensure homogeneous distribution of the conidia. The wounds were inoculated with $G$. cingulata 7,5 , and 0 days before inoculation with 25 $\mu \mathrm{l}$ of L. monocytogenes cells $\left(10^{6} \mathrm{CFU} / \mathrm{ml}\right.$ in $0.85 \% \mathrm{NaCl}$ ). Another set of apples was inoculated with spores of P. expansum 5, 2, and 0 days before inoculation with $25 \mu$ of L. monocytogenes cells $\left(10^{5} \mathrm{CFU} / \mathrm{ml}\right.$ in $0.85 \% \mathrm{NaCl})$. Fungal inoculum in the apples was allowed to dry for $1 \mathrm{~h}$, after which fruit were placed in a tray pack box with a perforated polyethylene liner and stored at

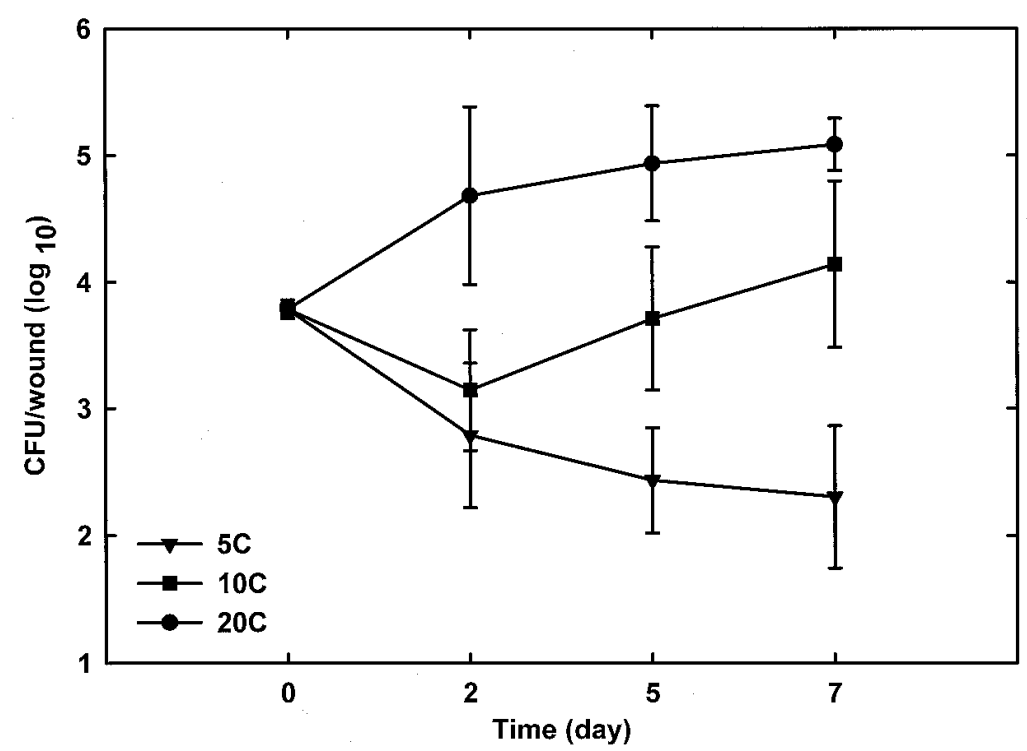

Fig. 3. Growth of Listeria monocytogenes on cv. Delicious apple slices. The slices were inoculated with the bacterium $\left(1 \times 10^{5} \mathrm{CFU} / \mathrm{ml}\right)$ and bacterial populations were recovered after incubation in air at 5,10 , and $20^{\circ} \mathrm{C}$ for various periods of time. Vertical bars indicate standard errors of the means.

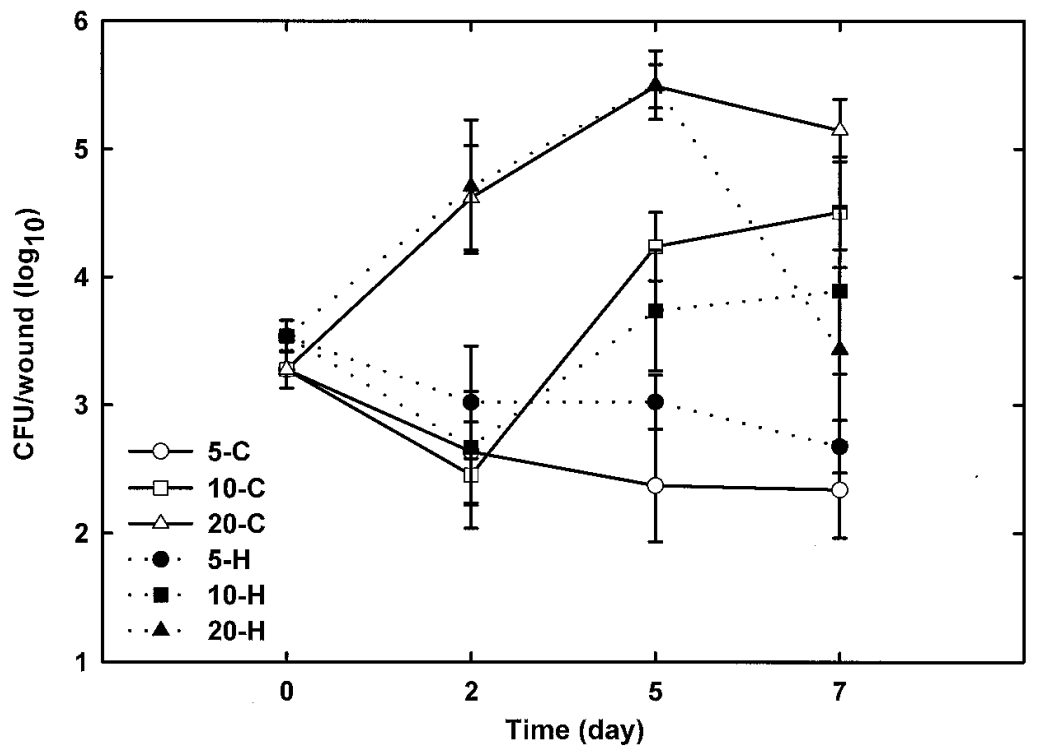

Fig. 4. Recovery of Listeria monocytogenes from apple slices inoculated with bacterial cultures grown at $30^{\circ} \mathrm{C}(\mathrm{H})$ or $5^{\circ} \mathrm{C}(\mathrm{C})$ prior to inoculation. The apple slices were incubated at 20,10 , and $5^{\circ} \mathrm{C}$. Vertical bars indicate standard errors of the means. 
$20^{\circ} \mathrm{C}$. The apples inoculated with both fungi and bacteria were incubated at 10 or $20^{\circ} \mathrm{C}$. There were four apples per treatment. L. monocytogenes was recovered from the wounds at 0,2 , and 5 days after inoculation with the bacterium as described previously, except that $10 \mu \mathrm{g} / \mathrm{ml}$ cycloheximide was added to the TSA plates to inhibit growth of the fungi. The $\mathrm{pH}$ of the apple tissue at the wound site was measured with a $\mathrm{pH}$ combination electrode, Semi-Micro (81-03 Ross, Orion Research, Inc., Beverly, MA).

Statistical data analysis. Data were analyzed using the mixed model analysis of variance procedure (SAS Institute, Cary, NC). Examination of variance heterogeneity among treatments indicated that the
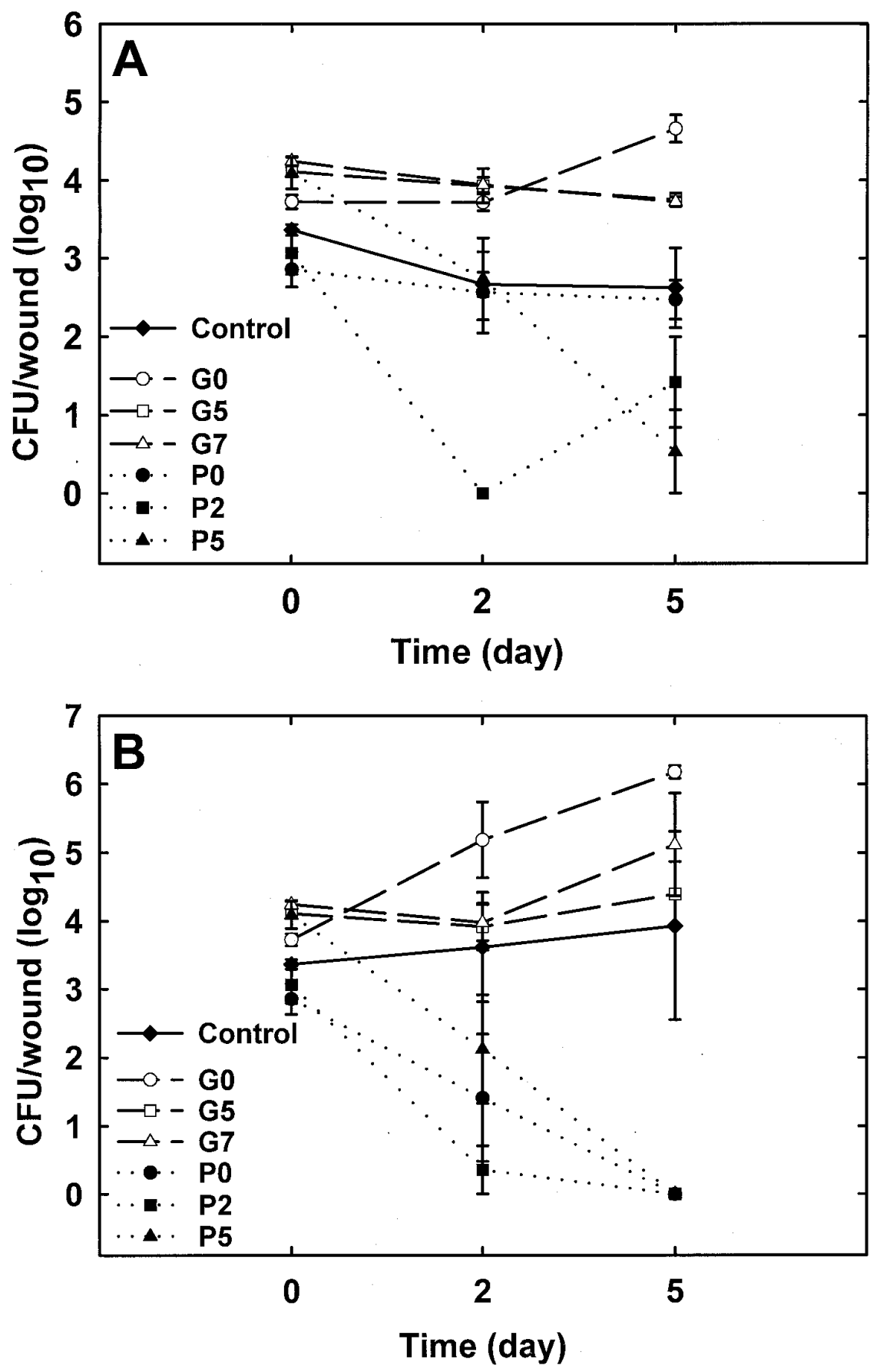

Fig. 5. Interaction of Listeria monocytogenes with Glomerella cingulata or Penicillium expansum on fresh cut apples at (A) $20^{\circ} \mathrm{C}$ and (B) $10^{\circ} \mathrm{C}$. Recovery of L. monocytogenes was performed at 0,2 , and 5 days after inoculation with the bacterium. Infection with P. expansum (P) or G. cingulata (G), respectively, at the time of inoculation with $L$. monocytogenes ( $\mathrm{P} 0, \mathrm{G} 0)$. Infection with P. expansum 2 (P2) and 5 (P5) days prior to inoculation with $L$. monocytogenes, respectively. Infection with $G$. cingulata 5 (G5) and 7 (G7) days prior to inoculation with L. monocytogenes, respectively. Vertical bars indicate standard errors of the means.

random experimental variance should be partitioned into two to four experimental variances, respectively. Group comparisons and factorial interactions were evaluated by contrasts. The design was balanced. A slice represented one sample; four randomized slices from different fruit were analyzed for each treatment. The data were normally distributed. Treatment means were separated at $P \leq 0.05$ using Tukey's multiple comparison test for Figures 1 to 4, and simple contrasts for Figure 5. Unless stated otherwise, only results significant at $P \leq 0.05$ are discussed.

\section{RESULTS}

Growth in apple juice. In apple juice, there was a steady decline of $L$. monocytogenes populations over time. The $\mathrm{pH}$ of the apple juice was 3.42 over the course of the experiment. No bacteria were recovered from 25 or $50 \%$ apple juice after a $24-\mathrm{h}$ incubation period and from $100 \%$ apple juice after $48 \mathrm{~h}$ (Fig. 1).

Effect of inoculum concentration. Over the 72-h period during which the bacterial colonies were sampled, the bacterial population increased by over two log units on slices inoculated with the bacterial suspension at $1 \times 10^{6}$ or $1 \times 10^{7} \mathrm{CFU} / \mathrm{ml}$ but only by one $\log$ unit on slices inoculated with the $1 \times 10^{8}$ suspension.

Effect of atmosphere and temperature. Storage atmosphere had no effect on populations of L. monocytogenes recovered from apple slices at three different temperatures (Fig. 2A and B), but the visual quality of the slices was better in controlled-atmosphere storage than in air storage. Over time, bacterial populations increased by approximately one $\log$ unit at $20^{\circ} \mathrm{C}$ (Fig. 3). There was no increase in populations at $5^{\circ} \mathrm{C}$, but the bacteria did survive at this temperature over the 12-day duration of the study. L. monocytogenes populations were significantly higher at 20 than at $5^{\circ} \mathrm{C}$ throughout the experiment (Fig. 3).

Effect of culture growth conditions of L. monocytogenes. There was no significant difference in the growth of L. monocytogenes regardless of previous growth temperature $\left(5\right.$ or $30^{\circ} \mathrm{C}$; Fig. 4$)$. There was no significant effect of the growth conditions on the subsequent growth of the bacteria on apple slices stored at three different temperatures.

Interactions between $L$. monocytogenes and fungi. L. monocytogenes populations recovered from apple slices decayed by $G$. cingulata were significantly higher than those decayed by $P$. expansum at 20 and $10^{\circ} \mathrm{C}$ (Fig. $5 \mathrm{~A}$ and B). After an incubation period of 2 to 5 days, no bacteria were detected on apples decayed by $P$. expansum. $P$. expansum also lowered the $\mathrm{pH}$ of the apple tissue from 4.7 to 3.7 after 2 days at the wound site. G. cingulata increased the $\mathrm{pH}$ from 4.7 to between 6.5 and 7.0 at the wound site 2 days after inoculation with L. monocytogenes. 


\section{DISCUSSION}

Wounded apple tissue supported not only the survival but also the growth of $L$. monocytogenes, especially at the higher temperatures of 10 and $20^{\circ} \mathrm{C}$. The fact that there was only a one-log-unit increase in the bacterial population on slices inoculated with the bacterial suspension at $1 \times$ $10^{8}$ indicated that the carrying capacity of the fruit wounds was reached sooner than with the two lower bacterial concentrations. The growth of the bacterium on apple slices probably resulted from its ability to modify the immediate micro-environment. This type of environmental modification would not occur in a liquid medium, such as apple juice, in which the bacterium did not survive for extended periods of time.

Controlled atmosphere is beneficial in extending the shelf life of various fruits and vegetables $(10,12)$. In our work, the low $\mathrm{O}_{2}$ concentration of $0.5 \%$ had no significant effect on the growth of the bacterium. However, it maintained the quality of the slices better than air storage. Exposure of fruits and vegetables to $\mathrm{O}_{2}, \mathrm{CO}_{2}$, or both at levels beyond their tolerance limits at specific temperature/time combinations results in stress to the living plant tissue leading to various physiological maladies, one of which is off-flavor due to a shift to anaerobic respiration $(8,11)$. If exposed for a shorter period of time, a given commodity may tolerate lower levels of $\mathrm{O}_{2}$ and higher levels of $\mathrm{CO}_{2}$ than would normally be recommended. Fresh-cut fruits and vegetables have fewer barriers to gas diffusion and can tolerate lower concentrations of $\mathrm{O}_{2}$ and higher concentrations of $\mathrm{CO}_{2}$ than intact commodities. In our work, we were able to go below the level of 1 to $5 \%$ $\mathrm{O}_{2}$ normally recommended for the intact product, due to the short storage duration and the use of fresh-cut apples $(11,17)$.

The growth of L. monocytogenes LCDC 81-861 in shredded lettuce was not affected when stored in a controlled atmosphere containing $3 \% \mathrm{O}_{2}$ and $97 \% \mathrm{~N}_{2}$ (5). This same strain of the pathogen on asparagus, broccoli, or cauliflower was also unaffected by controlled atmosphere storage (3). Controlled-atmosphere storage would probably not be used to any great extent with fresh-cut products because of the short handling period. However, atmospheres within film-packed fresh-cut products become modified and this modified atmosphere packaging can have the same effect as controlled atmosphere when the gas mixtures are similar (16). Modifying the packaging or storage atmosphere has a positive effect on prolonging the shelf life of the fresh-cut fruit; however, it probably will not prevent the increase of $L$. monocytogenes populations, especially at higher temperatures $\left(\geq 10^{\circ} \mathrm{C}\right)$.
Very little research has described the association and interaction of plant and human pathogens on fruits and vegetables (9). In this study, L. monocytogenes populations continually increased on fruit decayed by $G$. cingulata, but the bacterium was not able to survive over time when inoculated onto fruit decayed by $P$. expansum. One of the major factors associated with the survival and growth of the foodborne pathogen could be the change in $\mathrm{pH}$ which occurred as the plant pathogens colonized the fruit. The $\mathrm{pH}$ of the decayed tissue increased as the decay caused by $G$. cingulata progressed, but decreased as the decay caused by $P$. expansum developed. The substrate, as modified by G. cingulata, was more suitable for survival and growth of $L$. monocytogenes than the substrate modified by $P$. expansum. Other factors in the apple tissue which affect growth and survival of L. monocytogenes may be modified by these postharvest pathogens and will require further study.

Our study shows that the temperature at which the fresh-cut fruit is stored is critical to minimize health risks from $L$. monocytogenes, as is the absence of postharvest pathogens like $G$. cingulata, which has a stimulating effect on populations of $L$. monocytogenes. This indicates potential interactions between postharvest plant pathogens and food-borne human pathogens. Similarly, a study involving more than 400 samples each of healthy and softrotted commodities collected in retail markets revealed that the incidence of Salmonella spp. on produce affected by bacterial soft rot was twice that of healthy samples $(3,18)$. The presence of soft rot on produce also affected concentrations of food-borne human pathogens. There were 37 times more Salmonella spp. in wash water from soft-rotted samples than from healthy samples. Controlled experiments with potato, carrot, and pepper tissues inoculated with a strain of Salmonella confirmed that bacterial soft-rot infection increased multiplication of Salmonella spp. by at least 3- to 10-fold compared with multiplication on uninfected tissues. The study concluded that, given the fact that Salmonella spp. can survive and grow on contaminated, fresh-cut surfaces of tomatoes and other vegetables, sanitation and treatments such as chlorination should be practiced in the marketing channels between the packing house and final consumption (18).

Although L. monocytogenes can grow on apple slices, the population of the bacterium will not increase if the temperature at which the slices are stored is low enough. Therefore, even if the fresh-cut fruit does become contaminated with the bacterium, the potential for any possible harm to the consumer will be minimized if the fruit is kept at the recommended refrigeration temperature of $4^{\circ} \mathrm{C}$.

\section{ACKNOWLEDGMENTS}

We thank G. A. Brown, C. Sharer, and M. Auldridge for valuable technical assistance.

\section{LITERATURE CITED}

1. Anonymous. 1994. Foodborne pathogens: risk and consequences. Task force report. Coun. Agric. Sci. Technol. no. 122. Ames, Iowa.

2. Bean, N. H., and Griffin, P. M. 1990. Foodborne disease outbreaks in the United States, 1973-1987: pathogens, vehicles, and trends. J. Food Prot. 53:807-814.

3. Berrang, M. E., Brackett, R. E., and Beuchat, L. R. 1989. Growth of Listeria monocyto genes on fresh vegetables stored under controlled atmosphere. J. Food Sci. 52:702-705.

4. Beuchat, L. R. 1996. Pathogenic microorganisms associated with fresh produce. J. Food Prot. 59:204-216.

5. Beuchat, L. R., and Brackett, R. E. 1990. Growth of Listeria monocytogenes on lettuce as influenced by shredding, chlorine treatment, modified atmosphere packaging, temperature and time. J. Food Sci. 55:755-758, 870.

6. CDC 1990. Foodborne diseases outbreaks. 5year summary, 1983-1987. Pages 15-57 in Morbid. Mortal. Weekly Rep. no. 39(SS-a).

7. Farber, J. M., and Peterkin, P. I. 1991. Listeria monocytogenes, a food-borne pathogen. Microbiol. Rev. 55:476-511.

8. Gorris, L. G. M., and Peppelenbos, H. W. 1992. Modified atmosphere and vacuum packaging to extend the shelf life of respiring food products. HortTechnology 2:303-309.

9. Heisick, J. E., Wagner, D. E., Nierman, M. L., and Peeler, J. T. 1989. Listeria spp. found on fresh market produce. Appl. Environ. Microbiol. 55:1925-1927.

10. Kader, A. A. 1993. A summary of controlled atmosphere experiments and recommendations for fruits other than pome fruits. Pages 859-887 in: Proc. Sixth Int. Controlled Atmosphere Res. Conf. Ithaca, NY.

11. Kader, A. A., Zagory, D., and Kerbel, E. L. 1989. Modified atmosphere packaging of fruits and vegetables. Crit. Rev. Food Sci. Nutr. 28:1-30.

12. Saltveit, M. E., Jr. 1993. A summary of CA and MA requirements and recommendations for the storage of harvested vegetables. Pages 800-818 in: Proc. Sixth Int. Controlled Atmosphere Res. Conf. Ithaca, NY.

13. Seeliger, H. P. R., and Jones, D. 1986. Genus Listeria Pirie. Pages 1235-1245 in: Bergey's Manual of Systematic Bacteriology, 9th ed. P. H. A. Sneath, ed. Williams \& Wilkins, Baltimore.

14. Sheridan, J. J., Duffy, G., Buchanan, R. L., McDowell, D. A., and Blair, I. S. 1994. The use of selective and non-selective enrichment broths for the isolation of Listeria species from meat. Food Microbiol. 11:439-446.

15. Sizmur, J. K., and Walker, C. W. 1988. Listeria in prepacked salads. Lancet i:1167.

16. Watada, A. E., Ko, N. P., and Minott, D. A. 1996. Factors affecting quality of fresh-cut horticultural products. Postharvest Biol. Technol. 9:115-125.

17. Watada, A. E., and Qi, L. 1999. Quality of fresh-cut produce. Postharvest Biol. Technol. 15:201-205.

18. Wells, J. M., and Butterfield, J. E 1997. Salmonella contamination associated with bacterial soft rot of fresh fruits and vegetables in the marketplace. Plant Dis. 81:867-872. 